\title{
Factors Related with Knowledge of Basic Life Support among Members of Student Body Volunteer Organizations at Universitas Padjadjaran
}

\author{
Nur Fadilla, ${ }^{1}$ Irvan Afriandi, ${ }^{2}$ Ruli Herman Sitanggang, ${ }^{3}$ Elsa Pudji Setiawati ${ }^{2}$ \\ ${ }^{1}$ Faculty of Medicine Universitas Padjadjaran, ${ }^{2}$ Department of Public Health Faculty of Medicine, \\ Universitas Padjadjaran Bandung, Indonesia, ${ }^{3}$ Department of Anesthesiology and Intensive Care \\ Faculty of Medicine Universitas Padjadjaran/Dr. Hasan Sadikin General Hospital Bandung
}

\section{Abstract}

Background: Mortality caused by accidents remains a public health challenge. Prompt response during first aid accident may prevent disability or death. At Universitas Padjadjaran three student body volunteer organizations provide training in Basic Life Support as the component of first aid. They are Korps Sukarela Palang Merah Indonesia (KSR PMI), Perhimpunan Mahasiswa Pecinta Alam (PMPA) Palawa, and Unit Search and Rescue (SAR). This study aims to assess the level of Basic Life Support knowledge of the members in three organizations and the factors related with their knowledge.

Methods: The method used was a descriptive study carried out on subjects diagnosed with PSS at the National EThis was a cross sectional study that included 59 members of three student body volunteer organizations of Universitas Padjadjaran that have received training in Basic Life Support. A questionnaire about respondent's characteristics, Basic Life Support-related experiences, and Basic Life Support's knowledge was administered to the participants during October 2012

Results: The total mean for the three student body volunteer organizations on questionnaire was $64.12 \pm 19.40$ with minimum score was 25 and maximum score was 100 . The interval of last period of training and Basic Life Support-related experiences did not show statistically significant $(\mathrm{p}=0.647)$ and $(\mathrm{p}=0.357)$ however educational background related to Basic Life Support knowledge showed statistically significant $(\mathrm{p}<0.01)$.

Conclusions: The level of Basic Life Support knowledge in three student body volunteer organizations was moderateand thateducationalbackground has relation with theknowledge. Theincreasein number ofeffective trainingandapplicationinthefield mayincreasetheknowledgeon BasicLifeSupport. [AM].2015;2(1):186-90]

Keywords: Basic Life Support, Knowledge, student body volunteer organizations

\section{Introduction}

Mortality caused by accidents remains a public health challenge. According to World Health Organization (WHO), the number of death from traffic accidents in the world reaches 2.4 million/year, ${ }^{1}$ whereas International Labour Organization (ILO) estimates that every year 2 million people die from workplace accidents worldwide. ${ }^{2}$ United Nations International Strategy for Disaster Reduction (UNISDR ) reported that during 1980-2010, there had been 321 natural disasters, accounted for 6.209 deaths per year. ${ }^{3}$

Prompt response during first aid accident can prevent disability or death. First aid is a means in emergency state that aims to prevent disability or death. ${ }^{4}$ Communities has an important role because they are the subject closest to the accidents, either being a victim or a helper for the victims in the accident. They need to be empowered as the first responder. In doing so they need to be trained in first aid. ${ }^{5}$

Three student body volunteer organizations at Universitas Padjadjaran provide training in Basic Life Support (BLS) as the component of first aid. They are Korps Sukarela Palang Merah Indonesia (KSR PMI) Universitas Padjadjaran, Perhimpunan Mahasiswa Pecinta Alam (PMPA) Palawa Universitas Padjadjaran, and Search and Rescue (SAR). KSR PMI Universitas Padjadjaran is a student organization under the supervision of Palang Merah Indonesia that volunteer in social and humanity activities. Palawa Universitas Padjadjaran is student body organization whose activities are based on adventure, social, environmental, and

Correspondence: Nur Fadilla, Faculty of Medicine, Universitas Padjadjaran, Jalan Raya Bandung-Sumedang Km.21, Jatinangor, Sumedang, Indonesia, Phone: +6285691684546 Email: nurfadilla23@gmail.com 
Nur Fadilla, Irvan Afriandi, Ruli Herman Sitanggang, Elsa Pudji Setiawati: Factors Related with Knowledge 187 of Basic Life Support among Members of Student Body Volunteer Organizations at Universitas Padjadjaran

humanity. Unit SAR Universitas Padjadjaran is a humanitarian student organization that provides support in natural disaster. Their activities include management before, at the moment, and after the disaster.

As these student body organizations perform BLS to provide first aid to save lives, the knowledge they carry about BLS becomes an important issue. Without proper knowledge, they would not be able to perform proper first aid. This study aims to assess the BLS knowledge level of the members in the three student body organizations and the factors related with their knowledge. This study results in feedback for evaluation for further organizational improvement.

\section{Methods}

This was a cross sectional study conducted during October 2012. The population of this study was all members of the three student body volunteer organizations at Universitas Padjadjaran, namely KSR PMI Universitas Padjadjaran, PMPA Palawa Universitas Padjadjaran, and Unit SAR Universitas Padjadjaran. They were included in this study if actively registered as the members during 2012. Those who did not present at the time of data collection and/or denied to participate in this study were excluded. All eligible members were asked to fill out questionnaire.

The questionnaire consists of 17 questions covering information regarding respondent's characteristics, BLS-related experiences, and knowledge about BLS. The characteristic information includes name of the organization, age, gender, address and educational background. BLS related experiences were asked to indicate the extent of the last BLS training period and to confirm whether a member had applied his/her BLS skills. The BLS knowledge was measured by 13 truefalse question formats. The questionnaire was piloted to a group of students as members of the student body other than the three student body volunteer organizations in the same university. Results of the pilot study showed that the questionnaire on BLS knowledge had a Cronbach's Alpha 0.671. Incomplete data filled during the study were returned to the respondents to be completed. All data collected were keyed in and analyzed using SPSS $₫$ for Windows ${ }^{\circledR}$ version 15.0 .

Univariate analysis was used to describe the respondent's characteristics, Data were presented as frequency distribution. Numerical data were tested for normality using Kolmogorov-Smirnov test. Since the data distribution was not normal, Spearman correlation test was used to examine the relationship between BLS knowledge and interval of last period of training, whereas

Table 1 Distribution Characteristics ofThe Study Participants

\begin{tabular}{lccc}
\hline \multicolumn{1}{c}{ Variables } & Frequency & $\mathbf{\%}$ & Mean \pm SD \\
\hline Organization & 19 & 32.2 & \\
$\quad$ KSR PMI & 13 & 22 & \\
PMPA Palawa & 27 & 45.8 & $20.34 \pm 1.66$ \\
$\quad$ Unit SAR & & & \\
Ages & & & \\
Gender & 30 & 50.8 & $12.24 \pm 9.16$ \\
$\quad$ Male & 29 & 49.2 & \\
$\quad$ Female & & & \\
Last period training (months) & & 30.5 & \\
Educational Background & 18 & 69.5 & \\
$\quad$ Medical Faculty & 41 & & \\
$\quad$ Nonmedical Faculty & & 16.9 & \\
Had applied BLS skills & 10 & 83.1 & \\
Yes & 49 & & \\
No & & & \\
\hline
\end{tabular}


Table 2 Distribution of the Study Participants by the Organization

\begin{tabular}{lcccc}
\hline \multicolumn{1}{c}{ Variable } & KSR PMI & PMPA Palawa & Unit SAR & Total \\
\hline Gender & 1 & 6 & & \\
$\quad$ Male & 18 & 7 & 23 & 30 \\
Female & 18 & 0 & 4 & 29 \\
Educational Background & 1 & 13 & 0 & 18 \\
$\quad$ Medical Faculty & 1 & & 27 & 41 \\
Nonmedical Faculty & 18 & 2 & 7 & 10 \\
Had applied BLS skills & 11 & 20 & 49 \\
Yes & & &
\end{tabular}

the relationship of BLS knowledge with educational background and BLS knowledge with BLS related experience was examined using Mann-Whitney comparative test. Statistical significance of the test was set at the level of 0.05 . The ethical approval for this study was obtained from the Health Research Ethic Committee, Faculty of Medicine, Universitas Padjadjaran (No 238/UN6.C2.1.2/ KEPK/2012).

\section{Results}

Most patients were in the age group of 31-A total of 59 members of student body volunteer organizations participated in this study. Among them 19 were from KSR PMI Universitas Padjadjaran, 13 were from PMPA Palawa Universitas Padjadjaran, and 27 participants were from Unit SAR Universitas Padjadjaran. The mean ages of the participants was 20.34 $(S D=1.66)$ and the number of male and female participants were almost equal. Most of the participants were from non-medical faculty and admitted never applied BLS skills. Table 1 shows information about characteristics of the study participants.

The range of ages in three student body volunteer organizations was quite varied. The age ranged from 18-22 years, 18-23 years, and 19-26 years in KSR PMI Universitas Padjadjaran, PMPA Palawa Universitas Padjadjaran, and Unit SAR Universitas Padjadjaran, respectively. The mean ages were 19.37 (SD=1.12) in KSR PMI Universitas Padjadjaran, 19.8 (SD=1.21) in PMPA Palawa Universitas Padjadjaran, and $21.26(\mathrm{SD}=1.70)$ in Unit SAR Universitas Padjadjaran. The female participants were predominately from KSR PMI Universitas Padjadjaran and male participants were predominately from Unit SAR Universitas Padjadjaran. All medical faculty participants were the members of KSR PMI Universitas Padjadjaran. The length of the last training ranged from 4-35 months, 4-7 months, 5-40 months in KSR PMI Universitas Padjadjaran, PMPA Palawa Universitas Padjadjaran, and Unit SAR Universitas Padjadjaran, respectively. The mean of last period of training were 11.21 (SD=6.86) in KSR PMI Universitas Padjadjaran, $5.54(\mathrm{SD}=0.97)$ in PMPA Palawa Universitas Padjadjaran, and 16.19 (SD=10.71) in Unit SAR Universitas Padjadjaran. Table 2 shows frequency distribution of the study participants based on the student body organization.

The total mean score on the BLS knowledge questionnaire was $64.12(\mathrm{SD}=19.40)$ with the minimum score was 25 and maximum

Table 3 Score of BLS Knowledge by the Organization

\begin{tabular}{lccc}
\hline & KSR PMI & PMPA Palawa & Unit SAR \\
\hline Min & 33.33 & 33.33 & 25 \\
Max & 100 & 66.67 & 83.33 \\
Mean \pm SD & $81.14 \pm 18.18$ & $46.79 \pm 10.51$ & $60.49 \pm 13.59$ \\
Median \pm IQR & $91.67 \pm 25$ & $50 \pm 16.67$ & $58.33 \pm 16.67$ \\
\hline
\end{tabular}


Nur Fadilla, Irvan Afriandi, Ruli Herman Sitanggang, Elsa Pudji Setiawati: Factors Related with Knowledge of 89 Basic Life Support among Members of Student Body Volunteer Organizations at Universitas Padjadjaran

Table 4 BLS Knowledge Level

\begin{tabular}{lccccc}
\hline & KSR PMI & PMPA Palawa & Unit SAR & Total & Frequency \\
\hline Good & 10 & 0 & 0 & 10 & $17 \%$ \\
Moderate & 8 & 7 & 24 & 39 & $66 \%$ \\
Poor & 1 & 6 & 3 & 10 & $17 \%$ \\
\hline
\end{tabular}

score was 100. The total median score on the questionnaire was 58.33 (SD=33.33). Table 3 shows the score of BLS knowledge by the organization. KSR PMI Universitas Padjadjaran had the highest mean score followed by Unit SAR Universitas Padjadjaran and then PMPA Palawa Universitas Padjadjaran.

The score of BLS knowledge was classified as good, moderate, or poor based on the mean and standard deviations. Table 4 shows the BLS knowledge level. More than $60 \%$ of study participants have moderate score. KSR PMI Universitas Padjadjaran, Unit SAR Universitas Padjadjaran, and PMPA Palawa Universitas Padjadjaran dominated the good, moderate, and poor BLS knowledge level.

Spearman correlation statistic test showed that the score of BLS knowledge was not related to the interval of last period training $(r=0.061, p=0.647)$. These data demonstrated that the BLS knowledge score of members was not affected by the training done in recent or older time.

The score of BLS knowledge was positively related to educational background. The MannWhitney U score was $111.500(\mathrm{p}<0.01)$. These data showed that the participants from medical faculty had better score of BLS knowledge than the participants from non-medical faculty. All medical faculty participants were the member ofKSR PMI Universitas Padjadjaran who had mean score of 81.14 ( $\mathrm{SD}=18.18$ ), while 46.79 $(S D=10.51)$ and $60.49(S D=13.59)$ was the mean for PMPA Palawa Universitas Padjadjaran and Unit SAR Universitas Padjadjaran.

The score of BLS knowledge was not related to BLS related experience as shown by the result of Mann-Whitney comparative test $(U=200.000, p=0.357)$. These results indicated there was no difference in the score of BLS knowledge between the participants who had applied and never applied his/her BLS skills.

\section{Discussions}

The total mean score on the BLS knowledge questionnaire among three student body volunteer organizations was 64.12 ( $\mathrm{SD}=19.40)$. This score reveals a moderate BLS knowledge level. The score of BLS knowledge in this study does not relate to the interval of last period training $(\mathrm{r}=0.061, \mathrm{p}=0.647)$. The possible explanation would be the BLS knowledge is influenced by other factors that affect the effectiveness of training and can affect the knowledge obtained from the training. 6 This factorsmainlycomefrom trainee characteristics such as intelligence, self-efficacy, motivation to learn, learning goal orientation, performance goal orientation, and instrumentality of the training. ${ }^{7,8}$ Therefore, the results in this study is different from the current literature saying that someone's knowledge and skills in first aid can be forgotten quickly as early as 30 days post training, due to limitation of knowledge retention. ${ }^{9}$ The BLS knowledge in this study is not affected by limitation of knowledge but is most likely depending on each participant's understanding about BLS and the effectiveness of BLS training they have had before.

In this study, the participants from medical students had the highest mean score of BLS knowledge. The participants from medical faculty will be more often exposed to the BLS knowledge during academic activity. They will also receive knowledge based on their major, medical science. ${ }^{10}$ This may explain the reason they have better score of BLS knowledge than the participants from non-medical faculty. In addition $r$, the score of BLS knowledge was positively related to educational background $(U=111.500, p<0.01)$.

The score of BLS knowledge does not relate to knowledge application experience $(U=200.000, p=0.357)$. This result indicates there is no difference in the score of BLS knowledge between the participants who has or has never had the BLS before. A significant difference is discovered between the number of participants that have applied BLS skills (10 participants) and those who have never applied BLS skills (49 participants). Unfortunately, the number of participants that have applied BLS skills is too small and therefore the relation between BLS knowledge and BLS related experience could not be assessed.

The conclusions are the BLS knowledge level among student volunteer organization at Universitas Padjadjaran is moderate. Of the 
three factors studied on the influence in BLS knowledge, one has relation to BLS knowledge, the educational background. Yet, other factors, the interval of last period training and BLS related experience is not related to BLS knowledge. The results of this study indicate there is a need to improve BLS knowledge. Some efforts can be made to improve BLS knowledge such as by increasing the number of effective training, organizing a simulation of BLS, and increasing the participation of student volunteer organization in the activities that provide them opportunity to apply BLS. Further research about other factors that may affect BLS knowledge including trainee characteristics also needs to be performed.

\section{References}

1. Segre L. Human eye anatomy: parts of the 1. Pusat Komunikasi Publik Kementerian Kesehatan RI. Kecelakaan lalu lintas penyebab kematian nomor 3. Jakarta. 2011 [Cited 2012 April 15]; Available from: http://sehatnegeriku. com/kecelakaan-lalu-lintas-penyebabutama-kematian-nomor-3/.

2. ILO. Keselamatan dan kesehatan kerja di Indonesia. Manila: International Labour Organization. 2004.

3. United Nations International Strategy for Disaster Reduction. Indonesia Disaster Statistic. Geneva. 2010. [Cited 2012 April 15]; Available from: http://www. preventionweb.net/english/countries/ statistics / index.php?cid=80.

4. Kartono M. Pertolongan pertama. Jakarta: Gramedia Pustaka Utama. 2005

5. Direktorat Jenderal Bina Kesehatan Masyarakat. Kurikulum pelatihan penolong pertama kedaruratan. 2nd ed. Jakarta: Departemen Kesehatan RI; 2006.

6. Tannenbaum SI, Cannon-Bowers JA, Salas E, Methieu JE. Factors that influence training effectiveness: a conceptual model and longitudinal analysis. Orlando, Florida: Naval Training Systems Center Human, Systems Integration Division; 1993. p. 1654

7. Tziner A, Fisher M, Senior T, Weisberg J. Effects of trainee characteristics on training effectiveness. Int J Selection Assessment. 2007;15(2):167-74.

8. Quinones MA. Contextual influences on training effectiveness. In: Quinones MA, Ehrenstein A, editors. Training for a rapidly changing workplace: applications of psychological research. Washington DC: American Psychological Association.1997. p. 177-99.

9. Anderson GS, Gaetz M, Masse J. First aid skill retention of first responders within the workplace. Scand J Trauma Resusc Emerg Med. 2011;19:11.

10. Igwe MN, Bakare MO, Agomoh AO, Onyeama GM, Okonkwo KO. Factors influencing knowledge about childhood autism among final year undergraduate Medical, Nursing and Psychology students of University of Nigeria, Enugu State, Nigeria. Ital J Pediatr. 2010;36:44. 